\title{
HARMONISASI POLA ASUH KELUARGA TERHADAP KEMAMPUAN SOSIAL EMOSIONAL ANAK USIA DINI
}

\author{
Lusi Marlisa \\ Universitas Muhammadiyah Metro \\ Lusimarlisa1@gmail.com
}

\begin{abstract}
ABSTRAC
Diversity in early childhood growth and development is different for each individual. Learning experiences that are presented to young children must be adapted to the uniqueness of each individual, so that during the development period the child experiences a dynamic increase rather than static, supported by parenting patterns in shaping children's readiness and ability to process emotions and socialize in the community. Because the polemic that is felt right now, lies in the parenting patterns and attitudes that parents take when educating children. So what happens is parenting parents contribute personality to children when children become adults caused by choices and attitudes of parents while educating children.
\end{abstract}

\section{Keywords: Parenting, Emotional Social}

\begin{abstract}
ABSTRAK
Keberagaman dalam pertumbuhan dan perkembangan anak usia dini berbeda pada setiap individu. Pengalaman belajar yang disajikan kepada anak usia dini haruslah disesuaikan dengan keunikan masing masing individu, sehingga selama masa perkembangan anak mengalami peningkatan yang dinamis bukannya statis, ditopang dengan pola asuh orang tua dalam membentuk kesiapan dan kemampuan anak dalam mengolah emosi dan bersosialisasi dalam lingkungan masyarakat. Karena polemik yang dirasakan saat ini, terletak pada pola asuh dan sikap yang diambil orangtua saat mendidik anak. Sehingga yang terjadi adalah pola asuh orangtua memberi sumbangan kepribadian kepada anak ketika anak menjadi dewasa yang disebabkan oleh pilihan pilihan dan sikap orangtua selama mendidik anak.
\end{abstract}

\section{Keywords : Pola Asuh, Sosial Emosional}

\section{A. PENDAHULUAN}

Tolak ukur atau Indikator kemajuan suatu bangsa dapat kita lihat dari seberapa maju nya pendidikan dan pengajaran yang diberikan kepada anak-anak muda saat ini. Baik dari segi pengajaran dan pendidikan yang diberikan dalam sekolah maupun dalam keluarga. Semua bidang pendidikan tersebut bersinergi, kemudian membentuk kepribadian dan karakter dalam diri anak pada masa depan, dan turut menentukan arah dan majunya perkembangan suatu bangsa. Sementara itu, jika kita focus pada pendidikan anak usia dini dan kontribusi keluarga dalam 
menciptakan anak bangsa yang mempunyai karakter yang kuat dalam dirinya, maka dibutuhkan kesadaran yang tinggi dalam keluarga dengan memberikan pendidikan yang terbaik pada anakanaknya. Dengan menyediakan pendidikan yang berkualitas, sehingga nantinya anak memiliki kesiapan dalam memasuki dunia masyarakat dan dunia pendidikan di sekolah formal.

Maka dari itu terdapat beberapa aspek perkembangan pada anak usia dini yang harus benar benar dioptimalkan pada saat usia dini, beberapa diantaranya adalah perkembangan kognitif, nilai moral dan agama, bahasa, sosial emosional, fisik-motorik, dan seni. Akan tetapi yang menjadi titik fokus perbincangan kita dalam tulisan ini adalah aspek perkembangan sosial emosional terhadap pola asuh keluarga yang akan diuraikan lebih rinci pada pembahasan.

Sehingga pembelajaran sosial-emosional yang perlu dikembangkan pada anak usia dini. Pertama, yaitu belajar bersosialisasi diri, yang mana usaha untuk mengembangkan rasa percaya diri dan rasa kepuasan bahwa dirinya diterima dikelompoknya. Kedua, belajar berekpresi diri, belajar mengekpresikan bakat, pikiran dan kemampuannya tanpa harus dipengaruhi oleh keberadaan orang dewasa lainnya. Ketiga, belajar mandiri dan berdiri sendiri lepas dari pengawasan orang tua. Keempat, belajar bermasyarakat, menyesuaikan diri dengan kelompok dan mengembangkan keterbukaan. Belajar bagaimana berpartisipasi dalam kelompok, bekerja sama, saling membagi, bergiliran, dan bersedia menerima aturan aturan dalam kelompok. Maka dari itu tugas keluarga lah yang berperan penting untuk mendidik anak tersebut, supaya dalam diri anak terdapat kriteria yang telah disebutkan dalam beberapa point diatas. ${ }^{1}$ Sehingga kemampuan sosial emosional yang harus dikuasai pada anak usia dini mencakup beberapa aspek sebagai berikut: anak dapat menunjukkan ekpresi wajar saat marah, sedih, takut, bisa menjadi pendengar dan pembicara yang baik, sabar menunggu giliran dan terbiasa antri, mengenal aturan dan mengikuti aturan.

Permasalahan yang mendasar adalah terkadang orang tua telah "merasa" memberikan pendidikan/pola asuh yang baik bagi anaknya, akan tetapi orangtua lupa bahwa anak tidak sama dalam "merasa" telah diberikan pendidikan yang terbaik. Inti dari pembahasan ini adalah pola asuh bukan hanya tentang bagaimana orangtua merasa "telah" mengasuh anak dengan benar, akan tetapi juga tentang bagaimana anak merasa "telah" diasuh dengan benar oleh orangtuanya.

\footnotetext{
${ }^{1}$ Mansur, Pendidikan Anak Usia Dini Dalam Islam, Yogyakarta: Pustaka Pelajar, 2014. h, 58.
} 
Hal tersebut harus sangat perlu diperhatikan karena pola pikir anak masih bersifat egosentris hanya memandang dari sudut pandang dirinya sendiri, pola pikir anak belum mengerti bahwa orang lain dapat berpandangan berbeda dengan dirinya. Oleh sebab itu konsep "merasa" yang diterapkan ini dari kedua nya baik dari orangtua maupun anak, "merasa" telah diberikan pendidikan dan pengasuhan yang baik oleh keduanya.

Karena bagaimana pun kondisi kehidupan anak pada masa mendatang adalah akibat dari sikap-sikap dan pilihan pilihan yang diambil oleh orangtua terhadap situasi atau peristiwa yang terjadi. Yang perlu digarisbawahi di sini adalah sikap yang diambil oleh orangtua tergantung dari pola pikir kita sebagai orangtua dalam menerapkan pola asuh yang paling ideal bagi anak, sedangkan bagaimana orangtua berpikir (mindset) dibentuk dari keyakinan (belief) yang tertanam diwaktu sebelumnya. Waktu sebelumnya adalah sebagian besar adalah masa ketika anda (orangtua) masih anak-anak. ${ }^{2}$

Perlu diingat dan disegarkan kembali ingatan kita bahwa keluarga mempunyai peranan penting dalam pembentukan sektor perkembangan sosial dan emosional anak sehingga tumbuh menjadi pribadi yang kokoh dan kuat saat melakukan interaksi sosial dilingkungan masyarakat. Peranan keluarga dalam perkembangan sosial anak tidak hanya menyangkut perkara sosial ekonomi dan juga kebutuhan struktural keluarga dengan interaksi nya saja, akan tetapi pergaulan yang terjadi dalam keluarga turut menentukan dan memegang peranan penting terutama sikap dan kebiasaan dari orangtua. ${ }^{3}$

\section{B. METODE PENELITIAN}

Ditinjau dari permasalahan yang dikaji oleh penulis, maka dari itu metode penelitian yang penulis gunakan di sini menggunakan jenis penelitian pustaka dengan pendekatan kualitatif. ${ }^{4}$ Oleh sebab itu literatur utama yang di kaji dalam penelitian ini adalah buku serta jurnal-jurnal yang berkaitan dengan pola asuh keluarga dan sosial emosional anak sebagai penelitian kepustakaan, maka metode pengumpulan data yang dipergunakan adalah metode dokumentasi,

${ }^{2}$ Danang Baskoro, Menjadi Lebih Baik (Parent Healing), Jakarta: Alex Media Komputindo, 2019. H, 8.

${ }^{3}$ Ali Nugraha dkk, Metode Pengembangan Sosial Emosional, Tangerang Selatan: Universitas Terbuka, 2015, h. 4.15 .

${ }^{4}$ Lexy J Moleong, Metode Penelitian Kualitatif (Bandung: Remaja Rosdakarya, 1990), 2. 
yaitu data tentang variabel yang berupa buku, jurnal dan lain-lain. Sedangkan teknik analisis yang dipilih adalah deskriptif analisis.

\section{PEMBAHASAN}

Penelitian yang dikaji oleh Bagus Sumargo dan Theresa Novalia yang mengkaji hubungan hubungan kesejahteraan anak anak dari keluarga yang kurang mampu terhadap kemampuan sosial emosional seperti mampu mengatasi stres, memiliki visi, harga diri yang baik dan konsep diri yang baik, dengan tema Structural Equation Modelling for Determining Subjective WellBeing Factors of the Poor Children in Bad Environment. Secara umum, persentase terbesar berdasarkan kondisi sosial ekonomi keluarga dengan skor 3 dengan total persentase 53,20 persen dan skor rata-rata 3,07. Secara keseluruhan, indikator pada variabel kesehatan emosional sosial menunjukkan persentase yang cukup besar yang menunjukkan anak-anak miskin di lingkungan yang buruk di Kampung Pulo sebenarnya memiliki kondisi kesehatan emosi sosial yang baik. Di antara indikator-indikator ini, indikator yang memiliki persentase terendah adalah Peraturan Emosi. Dengan demikian, untuk masa depan perlu untuk memperhatikan dan melatih anak-anak kurang mampu untuk memiliki kemampuan untuk mengatur emosi lebih banyak sehingga mereka dapat mengekspresikan emosi positif dan mengelola emosi negatif mereka secara efektif. ${ }^{5}$

Kesimpulan yang penulis dapat simpulkan bahwa peranan keluarga dalam perkembangan sosial emsoional anak tidak hanya menyangkut perkara sosial ekonomi saja, akan tetapi terdapat peran keluarga dalam bentuk interaksi dan pergaulan yang turut menentukan dan memegang peranan penting terutama sikap dan kebiasaan orang tua turut memberikan sumbangsihnya terhadap terbentuknya kemampuan sosial emosional anak khususnya dalam mengelola emosi pada anak. Hal tersebut mudah untuk diterima apabila kita mengingat kembali bahwa keluarga merupakan sebuah kelompok sosial dengan tujuan, struktural, norma, dan dinamika kelompok, termasuk pola asuh yang diberikan akan sangat mempengaruhi kehidupan individu saat menjadi anggota kelompok.

${ }^{5}$ Bagus Sumargo et.al, Structural Equation Modelling for Determining Subjective Well-Being Factors of the Poor Children in Bad Environment, Journal Procedia Computer Science 135 (2018) 113-119, diakses pada tanggal: 24 juli 2019 pukul 14.06 WIB. 
Merujuk pada dimensi pola asuh orangtua, Maccoby mengatakan bahwa terdapat dua dimensi pembentukannya, yaitu yang pertama adalah dimensi control dan dimensi kehangatan. Dimensi control adalah dimensi yang berhubungan dengan sejauh mana orangtua mengharapkan dan menuntut kematangan anak serta tingkah laku yang bertanggung jawab dari anak. Misalkan pembatasan, tuntutan, campur tangan dan penggunaan kekuasaan orangtua kepada anak. Sedangkan dimensi kehangatan adalah dimensi yang mengarah kepada hubungan yang lebih dekat dengan anak dengan tingkat respon orang tua terhadap kebutuhan anak dalam penerimaan dan dukungan. Contohnya memberikan dukungan kepada anak, memperhatikan kesejahteraan anak, cepat tanggap, meluangkan waktu dalam kegiatan bersama, siap menanggapi kecakapan anak atau keberhasilan serta menunjukkan cinta kasih, serta peka terhadap emosi anak. ${ }^{6}$

Terdapat beberapa hasil penelitian yang dikemukakan oleh Lewin, Lippit, dan White mengenai bentuk pola asuh yang dapat mempengaruhi perkembangan sosial serta emosional anak untuk menjadi anggota kelompok masyarakat, dianataranya bentuk pola asuh yang umum terjadi dalam keluarga adalah otoriter, demokratis, dan laissez-faire. Berikut ini, penulis akan jelaskan lebih lanjut terhadap gaya kepemimpinan dalam keluarga terhadap perkembangan anak :

\section{a. Otoriter}

Pola asuh atau sikap orangtua yang bersifat otoriter tidak akan baik unuk perkembangan sosial anak dikarenakan hal tersebut dapat menjadikan anak menjadi takut, anak tidak taat, tidak ada inisiatif, dan menjadikan anak pasif, anak tidak dapat merencanakan sesuatu, kemudian anak mudah menyerah manakala mengahadapi situasi yang tidak bisa dikendalikan.

Sikap otoriter dalam hal ini adalah menentukan segala kegiatan seseorang secara otoriter, yang mana orangtualah yang menentukan dan memastikan apa yang akan dilakukan oleh anak. Sehingga anak dan orang lain tidak boleh ambil bagian dalam pengambilan keputusan yang telah dibuat dan tidak diajak untuk turut menentukan langkah langkah yang akan diambil dari keputusan yang ada. ${ }^{7}$

b. Demokratis

Sikap kepemimpinan demokratis disini mengajak anggota keluarga untuk menentukan bersama melalui musyawarah dan mufakat secara bersama sama dan terdapat keterbukaan daam

\footnotetext{
${ }^{6}$ Danang Baskoro, Op.Cit, h. 17.

${ }^{7}$ Ali Nugraha dkk, op.cit. h. 4.16.
} 
pengambilan keputusan. Sikap orangtua dalam mendidik anak memberikan saran saran mengenai berbaagai kemungkinan pelaksanaan kegiatan yang dapat mereka pilih sendiri mana yang terbaik. sikap dalam mendidik ini memberikan penghargaan dan kritik secara objektif dan positif. $^{8}$

c. Laissez faire

Sikap Laissez faire dalam mendidik anak terhadap perkembangan sosial anak. Sikap yang diambil adalah orangtua menjalankan peranan yang pasif sebagai seorang yang hanya bisa menonton atau mengamati. Orangtua menyerahkan segala penentuan tujuan dan kegiatan kelompok kepada angota keluarga nya masing masing. Orangtua tidak mnegambil inisiatif apapun dalam kegiatan yang diberikan kepada anak. Kehadiran orangtua berada ditengah tengah keluarga tetapi tidak berinteraksi hanya mengamati/ mengobservasi saja. ${ }^{9}$ pola asuh seperti ini tidak cocok untuk diterapkan pada anak usia dini, akan tetapi akan cocok bila diberikan kepada orang dewasa yang sudah matang pemikirannya.

Masih terdapat beberapa lagi jenis pola asuh selain dari yang penulis paparkan di atas. Beberapa dianatara nya adalah pola asuh permisif dan pola asuh diabaikan, yang penulis kutip dari buku Danang Baskoro yang berjudul Parent Healing. Dibawah ini adalah uaraian dari penjelasannya, sebagai berikut:

d. Pola asuh permisif

Pola asuh ini sangat berbalikan dnegan pola asuh otoriter. Yang mana pola asuh ini mempunyai dimensi control yang cukup rendah dan dimensi kehangatan yang tinggi. Orangtua sangat peduli akan dengan kebutuhan perasaan anak, akan tetapi kurang dalam memberikan control.

Dalam pola asuh ini hubungan anatara anak dan orang tua mempunyai hubungan yang cukup hangat dalam berinteraksi, namun orangtua lebih cendrung pada memanjakan anak. Anak diberikan kebebasan penuh dan anak dibiarkan memonitor aktivitasnya sendiri. Anak dalam lingkup pola asuh seperti ini akan mempunyai beberapa kesulitan salah satunya adalah kesulitan dalam menjalin relasi dengan orang lain, kemudian dalam pengendalian diri, serta dalam

\footnotetext{
8 W.A Dipl Gerungan, Psikologi Sosial, Bandung: Refika Aditama, 2009, h, 142.
}

${ }^{9}$ Ibid, h. 143. 
memahami emosi anak. Hal hal tersebut merupakan salah satu dampak yang ditimbulkan dari pola asuh yang permisif. ${ }^{10}$

e. Pola asuh diabaikan

Dibandingkan dengan pola asuh yang lainnya, pola asuh ini adalah pola asuh yang terburuk. Dianggap paling buruk karena jika dilihat dari dua dimensi yang telah di kemukakan oleh Maccoby terhadap dimensi control dan dimensi kehangatan sangat rendah sekali. Orangtua tidak hadir dan tidak dirasakan berperan banyak di kehidupan anak, dan tidak peka terhadap kebutuhan anak baik fisik maupun psikologis serta menarik diri secara emosional. Saat anak merasakan kesusahan, orangtua tidak tanggap dan tidak berusaha menunjukkan kepeduliannya, sehingga hal ini membuat anak merasa tidak dimengerti oleh orangtuanya. Disisi lain, orangtua juga tidak memberikan tuntutan apapun kepada anak. Tidak ada standar-standar atau target-targetyang harus dicapai anak dalam usia perkembangannya ataupun secara prestasi sekolah. Semuanya dibebaskan dan tidak ada pengontrolan. Dengan hal tersebut, akan berdampak pada anak sehingga mengalami hal seperti merasakan penolakan dari orangtua, merasa tidak disayangi, tempramen yang buruk, empati yang rendah, dan cepat merasakan depresi. ${ }^{11}$

Menurut pandangan penulis dalam menyimpulkan pola asuh yang cocok dalam keluarga, yang diambil dari uraian di atas adalah jenis pola asuh yang bersifat demokratis. Mengapa pandangan penulis lebih kepada pola asuh demokratis ? hal tersebut dikarenakan pengasuhan yang diberikan kepada anak lebih membuka kesempatan kepada anak untuk ikut andil dalam setiap keputusan dan lebih banyak memberikan anak pilihan-pilihan, sehingga menurut pandangan penulis pola asuh ini lah yang lebih ideal dalam keluarga.

Pandangan tersebut tidak menjadikan jenis pola asuh yang lainnya buruk atau menjadi tidak penting, akan tetapi semua pola asuh tersebut mempunyai kelebihan dan kekurangannya masing masing. Dalam artian semua pola asuh yang terdapat di atas dapat diberikan dan digunakan secara bergantian tergantung dengan situasi dan peristiwa pada saat itu terjadi. Jika kita kontekskan pola asuh terhadap perkembangan zaman saat ini, yang mana pada saat ini kemajuan dan teknologi yang sangat pesat berkembang, mengharuskan kita sebagai orangtua atau pendidik

${ }^{10}$ Danang baskoro, Op.Cit, H. 22.

${ }^{11}$ Ibid, h. 26. 
juga harus mengikuti perkembangan yang sedang berlangsung begitu pula dengan pola asuh yang diberikan kepada anak.

Dilemanya pada zaman sekarang ini ternyata cukup banyak pola asuh yang diberikan oleh orangtua atau keluarga yang bersifat permisif. Yang mana orangtua yang terlalu menuruti keinginan anaknya tanpa diimbangi dengan control yang tepat. Akibat yang dirasakan adalah secara mental anak-anak menjadi lemah, menjadi lebih egois, dan cepat merasa menyerah. Kemudian penguasaan terhadap emosi menjadi tidak terkendali.

Seperti pendapat yang dikatakan oleh Dorothy Law Nolte terhadap gaya pengasuhan dan pendidikan yang diberikan orang tua saat anak usia dini memberikan pengaruh terhadap perkembangan mentalnya baik itu positif maupun negatif. dalam ringkasannya menerangkan sebagai berikut :

Jika anak dibesarkan dengan celaan, ia belajar memaki

Jika anak dibesarkan dengan permusuhan, ia belajar berkelahi

Jika anak dibesarkan dengan ketakutan, ia belajar gelisah

Jika anak dibesarkan dengan rasa iba, ia belajar menyesali diri

Jika anak dibesarkan dengan olok-olok, ia belajar rendah diri

Jika anak dibesarkan dengan iri hati, ia belajar kedengkian

Jika anak dibesarkan dengan dipermalukan, ia belajar merasa bersalah

Jika anak dibesarkan dengan dorongan, ia belajar percaya diri

Jika anak dibesarkan dengan toleransi, ia belajar menahan diri

Jika anak dibesarkan dengan pujian, ia belajar menghargai

Jika anak dibesarkan dengan penerimaan, ia belajar mencintai

Jika anak dibesarkan dengan dukungan, ia belajar menyenangi diri

Jika anak dibesarkan dengan pengakuan, ia belajar mengenali tujuan

Jika anak dibesarkan dengan rasa berbagi, ia belajar kedermawanan

Jika anak dibesarkan dengan kejujuran dan keterbukaan, ia belajar kebenaran dan keadilan

Jika anak dibesarkan dengan rasa aman, ia belajar menaruh kepercayaan 
Jika anak dibesarkan dengan persahabatan, ia belajar menemukan cinta dalam kehidupan

Jika anak dibesarkan dengan ketentraman, ia belajar berdamai dengan pikiran. ${ }^{12}$

Dari pola asuh keluarga ini, anak akan belajar bagaimana menampilkan berbagai jenis emosi (seperti senang, sedih, marah, cinta, dll) yang akan ditunjukkan anak sebagai salah satu bentuk komunikasi mereka terhadap respon dari pola asuh orangtua. Melalui perubahan mimik wajah dan fisik yang menyertai emosi, anak anak dapat mengekpresikan dan mengkomunikasikan perasaan mereka kepada orang lain, dengan menunjukkan ekpresi kegembiraan, ketakutan, kebencian dan sebagainya. Tidak menutup kemungkinan hal tersebut akan sangat berpengaruh terhadap kehidupan sosial anak, ketika anak tidak bisa mengendalikan emosi yang dihasilkan atas reaksi emosinya sendiri yang merupakan respon terhadap lingkungan sekitar nya.

Keterkaitan pola asuh terhadap kemampuan sosial emosional anak, mempunyai ruang dominan yang kuat. Dalam kemampuan anak berinteraksi dalam lingkungan sekitar, sangat di tentukan oleh interaksi yang diterima anak selama dirumah, mengingat anak banyak menghabiskan sebagian besar waktunya di rumah. Sehingga dapat penulis katakan bahwa rumah merupakan dunia bagi anak dan sekolah pertama bagi anak dalam kehidupannya terutama dalam mengajarkan sosial dan emosional bagi anak.

Daniel goleman mengatakan bahwa emosi yang terdapat pada setiap orang adalah sama, yang mana merupakan salah satu dorongan untuk bertindak yang merupakan respon ketika seseorang sedang menghadapi suatu kondisi tertentu ataupun juga masalah. Jika melihat dari arti kata emosi sendiri movere yang berarti bergerak atau menggerakan, yang menyiratkan bahwa kecendrungan untuk bertindak merupakan hal mutlak dalam emosi. ${ }^{13}$ Dalam emosi anak yang diharapkan ia dapat mengenal emosi nya sendiri dan mampu mengelola emosi (marah, sedih, gembira, terkejut, kebahagian, cinta, rasa sedih) menjadi suatu yang dapat anak kendalikan dan dapat mengelolanya dengan baik. Anak akan belajar bagaimana mereka mengendalikan semua itu dari pola asuh yang diberikan orangtua selama di rumah dan interaksi yang diberikan

\footnotetext{
${ }^{12}$ Dorothy Law Nolte, Children Learn What They Live, Diakses Pada https://whywine.wordpress.com, Minggu 12 Juli 2019 Pukul 14.10 WIB

${ }^{13}$ Daniel Goleman, Emotional Intelligence, Alih Bahasa: T. Hermaya, Jakarta: Gramedia Pustaka Utama, 1996, h. 7.
} 
orangtua selama menghadapi masalah. Kemudian bagaimana oangtua sebagai role model yang memberikan contoh kepada anak bagaimana anak bertindak dalam mengelola emosi dalam keadaan sosial dalam keluarga.

Tugas orangtua dalam prinsip pengasuhan adalah menjadi teladan, mengingatkan dan memperbaiki melalui tiga hal yaitu sabar, kasih saying serta konsistensi. Pola asuh yang diberikan orang tua dapat penulis gambarkan seperti gambar dibawah ini

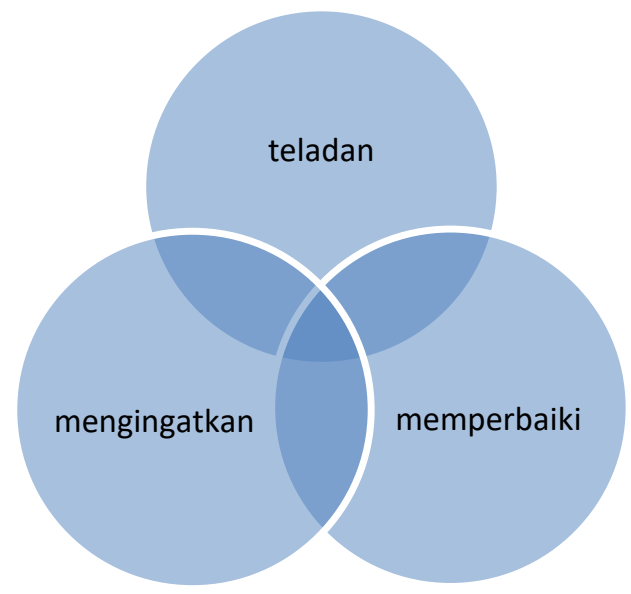

Essensi yang paling penting dalam pola asuh orangtua pada anak, sehingga menjadi suatu hal yang paling baik ketika hubungan dibangun kembali dengan tiga pilar seperti kesabaran, memberikan kasih sayang dan konsistensi dalam interaksi yang dibangun pada anak. ${ }^{14}$

Jika melihat kembali pada hubungan pola asuh orangtua dengan anak, maka akan terdapat siklus yang tidak akan pernah terputus dan akan kembali terulang, ketika pola asuh yang kita berikan sebagai orangtua menerapkan pola asuh yang salah kepada anak. Karena ketika anak sudah beranjak dewasa dan mempunyai anak, maka pola asuh yang pernah di terapkan dirumah pada saat anak masih kecil akan menjadi satu dasar atau rujukan bagi seseorang dalam pengasuhan selanjutnya.

\section{KESIMPULAN}

Dari paparan yang telah di uraikan di atas, penulis simpulkan bahwa sebagian besar waktu anak dihabiskan dalam rumah. Rumah bagi anak merupakan dunia yang sangat berpotensi untuk mengajarkan anak bagaimana bersosial dan mengatur emosional anak tersebut. Pola asuh yang diberikan oleh keluarga (terutama ibu dan ayah) tentunya sangat memberikan sumbangsih nya

\footnotetext{
${ }^{14}$ Okina Fitriani, Enlightening Parenting, Jakarta: Serambi Ilmu Semesta, 2019. H. 59.
} 
terhadap masa depan anak ketika hidup dalam lingkungan masyarakat yang lebih luas. Tugas orangtua dalam prinsip pengasuhan adalah menjadi teladan, mengingatkan dan memperbaiki melalui tiga hal yaitu sabar, kasih saying serta konsistensi. Hal tersebut akan menjadi hal yang sangat krusial bagi orangtua dan anak dalam membangun hubungan kedekatan sebagai salah satu interaksi yang terdapat di lingkungan keluarga.

Pola hubungan yang dibentuk dengan gaya kepengasuhan yang berbeda pada setiap keluarga, akan menghasilkan sifat dan karakter yang berbeda pada setiap anak. Karena tidak menutup kemungkinan terjadinya perbedaan-perbedaan yang mendasar pada setiap gaya kepengasuhan yang di berlakukan pada suatu keluarga dalam interksi antara orangtua dan anak.

Jika melihat kembali pada hubungan pola asuh orangtua dengan anak, maka akan terdapat siklus yang tidak akan pernah terputus dan akan kembali terulang, ketika pola asuh yang kita berikan sebagai orangtua menerapkan pola asuh yang salah kepada anak. Karena ketika anak sudah beranjak dewasa dan mempunyai anak, maka pola asuh yang pernah di terapkan dirumah pada saat anak masih kecil akan menjadi satu dasar atau rujukan bagi seseorang dalam pengasuhan selanjutnya.

\section{E. DAFTAR PUSTAKA}

Ali Nugraha dkk, Metode Pengembangan Sosial Emosional, Tangerang Selatan: Universitas Terbuka, 2015.

Danang Baskoro, Menjadi Lebih Baik (Parent Healing), Jakarta: Alex Media Komputindo, 2019.

Daniel Goleman, Emotional Intelligence, Alih Bahasa: T. Hermaya, Jakarta: Gramedia Pustaka Utama, 1996

Dorothy Law Nolte, Children Learn What They Live, Diakses Pada https://whywine.wordpress.com, Minggu 15 Oktober 2017, Pukul 14.10 WIB

Mansur, Pendidikan Anak Usia Dini Dalam Islam, Yogyakarta: Pustaka Pelajar, 2014.

Okina Fitriani, Enlightening Parenting, Jakarta: Serambi Ilmu Semesta, 2019.

W.A Dipl Gerungan, Psikologi Sosial, Bandung: Refika Aditama, 2009.

Bagus Sumargo et.al , Structural Equation Modelling for Determining Subjective Well-Being

Factors of the Poor Children in Bad Environment, Journal Procedia Computer Science 135 (113-119), 2018. 